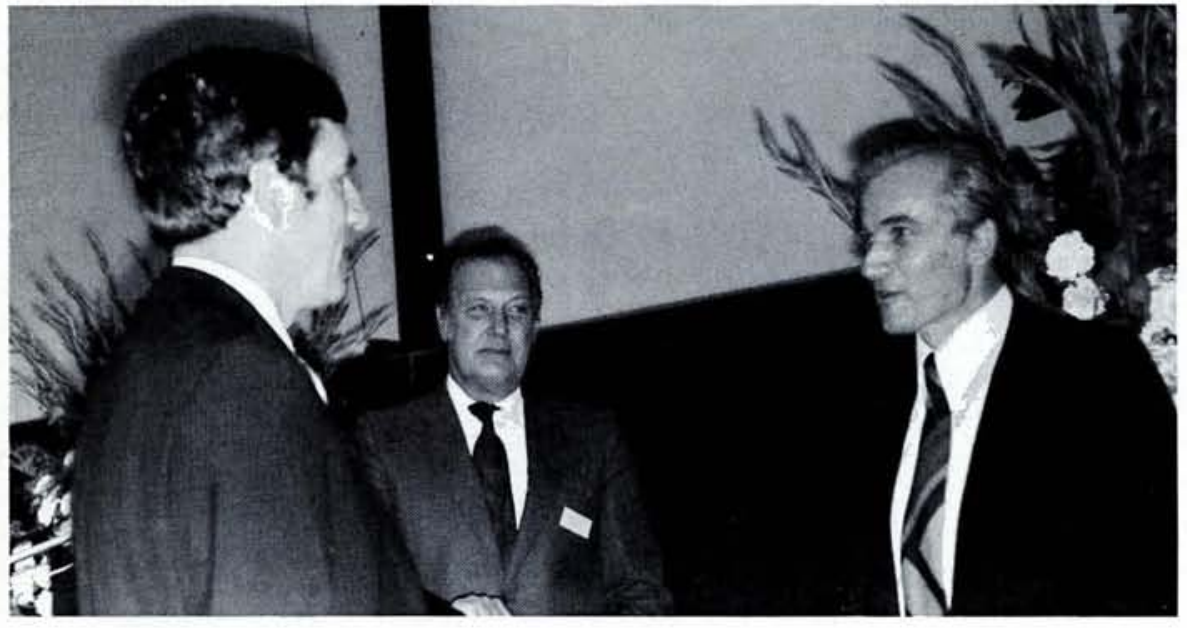

Professor W. Martienssen (right), vice-president of EPS makes the presentation of the 1976 Hewlett-Packard Europhysics Prize to Professor W. Helfrich at the opening of the Congress Ampere in Heidelberg on September 27 under the benevolent gaze of Mr. B.M. Oliver of Hewlett-Packard. Professor Helfrich in his acceptance speech spoke of the need for physicists to enter as a body into fields that had traditionally been the province of other disciplines. It was becoming more difficult for the individual to make his mark in the classical lines of physics development but the physics community had much to offer in related field's which presented a new challenge and new opportunity.

Following the presentation the Executive Committee of the EPS met in Heidelberg. Apart from routine business and the reports from the Divisions and Advisory Committees it discussed the proposals made in Council for an EPS coordinated foreign student scholarship scheme and the sponsorship of travelling lecturers. Consideration was also given to the offer made by the USSR Academy of Sciences for an Artsimovich Memorial Lecture.

\section{Chemical Physics Section Inaugurated}

About 120 chemical physicists (do not ask for a precise definition !) and about 40 accompanying persons from more than 20 countries of Europe and abroad assembled at the Free University in Amsterdam from 30 August1 September 1976 to inaugurate the new Section of Chemical Physics of the Atomic Physics Division. The framework for this inauguration was a scientific conference on the subject "Exploring the Chemical Bond. New Developments", at which eight invited lectures and about 50 short communications were presented for discussion, abstracts of which were published as volume 1G of the first series of Europhysics Conference Abstracts.

The Chemical Physics Section of the Atomic Physics Division recognizes, as was explained during the General Assembly Meeting in Amsterdam two types of participation:

a) membership by EPS Individual Ordinary Members and Member Organizations of EPS ;

b) the status of "participant" for those individuals and organizations not covered under $\mathrm{a}$ ).

In Amsterdam, the Provisional Board declared itself willing to be officially elected and take office until the next General Assembly Meeting or for a period not exceeding two

\section{Quantum Electronics Div.}

The second edition of 'Who's Who in Quantum Electronics', published by the Quantum Electronics Division is now available. In this 276 page A5 booklet, are listed organizations with research programmes in quantum electronics by country and by town. Under each organization is quoted its address, names of senior staff members, brief description of the research programme followed by references to papers published. Copies are available from Professor F.P. Schäfer, MaxPlanck-Institut für Biophysikalische Chemie, Am Fassberg, D-3400 Göttingen-Nikolausberg (Bank A/c: Kreissparkasse Göttingen No. 118006 064). Price to individuals and institutions: $15 \mathrm{DM}$; industrial organizations subscribing to first edition: $250 \mathrm{DM}$; other industrial organizations: $500 \mathrm{DM}$.

\section{Associate Member}

RCN, an Associate Member of EPS, will in future be known as $E C N$ (Stichting Energieonderzoek Centrum Nederland) or the Netherlands Energy Research Foundation. The change of title is related to the Government's resolution to broaden the scope of the foundation to cover the whole field of energy supply rather than just nuclear energy.

\section{Member Societies}

Professor I. Weinzierl of the Institute of Physics of the University of Vienna has been elected from 1 Oct. as president of the Austrian Physical Society.

The newly elected chairman of the governing board of the Danish Physical Society is Professor A.R. Mackintosh of the Ørsted Institute, Copenhagen University.

From 1 October, 1976 the new President of the UK Institute of Physics is Dr. B.J. Mason, of the Meteorological Office, Bracknell.

Chemical Reactions" in 1978 (these are very preliminary titles). In the meantime, a start will be made on a Chemical Physics Inventory of research and teaching in Europe, and means will be investigated for stimulating collaboration on various research projects.

Those interested in joining the Section are urged to contact the EPS Secretariat or the Section Secretary, Professor G. Wagnière, Institute of Physical Chemistry, University of Zürich, Rämistrasse 76, CH-8001 Zürich. L. Jansen
Editor : E.N. Shaw

Editorial Board:

G. J. Béné, B. Glovanninl, M. Guenin, B. Hauck, J. Muller, S. Newman

All correspondance to: EdItor, EUROPHYSICS NEWS, European Physical Soclety, P.O. Box 39,

CH-1213 Petit-Lancy 2 Phone: Geneva 931132 Switzerland.

Published by the European Physical Society Printed by: Ed. Cherix et Fllanosa SA CH-1260 Nyon, Switzerland 